\title{
Preparation of wastelage using poultry droppings with maize stover and its nutrient content as ruminant feed
}

\author{
MDK Jamee ${ }^{1,3}$, AKMA Kabir ${ }^{1}$, SMA Islam", MM Hossain ${ }^{2}$ and MRI Khan ${ }^{1 *}$ \\ ${ }^{1}$ Department of Animal Science, Bangladesh Agricultural University, Mymensingh-2202; ${ }^{2}$ Department of Poultry \\ Science, Bangladesh Agricultural University, Mymensingh; ${ }^{3}$ Central Cattle Breeding and Dairy Farm, Savar, \\ Dhaka
}

\begin{abstract}
An experiment was undertaken with caged layer excreta (CLE) treated maize stover and ensiled to investigate its potentiality as ruminant feed. Chopped maize stovers were preserved in plastic containers under airtight condition at room temperature based on the treatments as $\mathrm{T}_{0}(0 \% \mathrm{CLE}), \mathrm{T}_{1}(20 \% \mathrm{CLE}), \mathrm{T}_{2}$ ( $40 \% \mathrm{CLE})$ and $\mathrm{T}_{3}(60 \% \mathrm{CLE})$ to investigate physical quality, chemical composition, in vitro organic matter digestibility (IVOMD) and metabolizable energy (ME) content at 0, 30, 60 and 90 days. The CP and Ash were increased $(P<0.01)$ and $D M, O M$ and $C F$ were decreased $(P<0.01)$ in all the treatments $\left(T_{1}, T_{2}\right.$ and $\left.T_{3}\right)$ compared to controlled $T_{0}$. The OM content was decreased numerically with the ensiling time. The EE content was not significant $(P>0.01)$ with the treatments and ensiling time. The OMD and ME content were increased $(\mathrm{P}<0.01)$ with the ensiling time from 0 to 90 days. The physical quality (color, smell, and hardness) of maize stover were improved by CLE added treatments $\left(T_{1}, T_{2}\right.$ and $T_{3}$ ) after ensiling but $60 \%$ CLE treatment had some pungent smell in 90 days and less OMD and ME value was observed than that of $T_{2}$. Considering all the physical and chemical properties, among all the treatments, $40 \%$ and $60 \%$ CLE are acceptable for preparing wastelage. By comparing physical quality, nutritive value and chemical composition between $40 \%$ and $60 \%$ CLE treatments, the $60 \%$ CLE was better. Thus wastelage prepared from $40 \%$ CLE, $55 \%$ maize stover along with $5 \%$ molasses will be a potential source of ruminant feed as well as reduce the environment pollution by utilizing CLE.
\end{abstract}

Key words: wastelage, caged layer excreta, maize stover, ruminant feed

\section{Introduction}

Now a day, poultry industry is the most rapidly growing industry in Bangladesh. Total poultry population was 337.99 million in the year 20172018 (DLS, 2018). Poultry droppings increases simultaneously with the increase of poultry population. However, these droppings are not disposed properly which results environmental and health hazards near the farm and adjoining area. Most effective and easy solution of these problems is to use the excreta for feeding animals either by drying or ensiling with poor quality forages. Poultry wastes are higher in nutrient content and can be a good source of feed for ruminants (Fontenot et al., 1971). It contains about $28-30 \%$ crude protein out of which 36 $50 \%$ is true protein (Bhattacharya and Taylor, 1975). Poultry waste can be free of pathogens by ensiling (Hadjipanayiotou, 1982; Daniels et al., 1983) and deep stacking (Strickler, 1977). Properly utilized of animal wastes are valuable resources of nutrients which includes: sources of plant nutrients (Hossain et al., 2010), feed ingredients for farm animals, poultry and fish (Lu and Kevern, 1975), substrate for methane generation (Islam et al., 2013; Rathi, 2006), and substrate for microbial protein synthesis (Cook et al., 2011; Ritz et al., 2004). Utilization of animal wastes to produce microbial or insect protein is feasible technically but not economically. On the other hand, methane generation from animal wastes is technically feasible (Smith et al., 1989), but the wastes possess low monetary value for this purpose. Thus, the most feasible methods of recycling animal wastes are as sources of nutrients for animals. Nutrient content and digestibility of maize stover is more than any other straws. It contains about $6 \%$ crude protein and metabolizable energy (ME) value of about 9 MJ/Kg DM (McDonald et al., 1995).

Maize stover are being used as ruminant feed in some developing and developed countries. In our country, use of maize stover as ruminant feed is rarely seen. If it does the nutritional requirement of ruminant will be fulfilled in a great extent. It 
also decreases the environmental hazard and soil pollution. Maize stover may be chopped, ensiled and can be fed in a similar way to maize silage (McDonald et al. 1995). Agro-industrial wastes (cow-dung, poultry droppings, sugarcane bagasses, wood pulp, slaughter house waste and municipal waste) have attracted the attention to the nutritionists for their economical and nutritional potentialities for the feeding of animals (EI-Sabban et al. 1970; Reddy and Reddy, 1980). Wastelage is a fermented product produced by blending animal waste with a fermentable product and storing to ensile. When properly ensiled, wastelage is free of salmonella type microorganisms and parasitic nematodes, free of noxious odors, palatable to livestock, and economically competitive as an animal feed. (Mavimbela, 2000; Islam et al., 2018).

Ensiling of chopping maize stover along with poultry droppings and molasses may produce a good quality wastelage for feeding cattle having desire palatability, nutrient content and digestibility. (Harmon et al., 1975; Khatun et al., 2013). Panna et al. (2019) found that $30 \%$ and $45 \%$ poultry dropings are acceptable for preparing wastelage. So, ensiling maize stover with poultry excreta and molasses will increase crude protein and other nutritive value of the diet lowering the $\mathrm{pH}$ value and produce lactic acid producing bacteria which will facilitate the natural preservation. The aims of the study are to know the nutritive value of wastelage prepared from caged layer excreta (CLE) with maize stover and also to find out a convenient option of disposing poultry droppings.

\section{Materials and Methods}

\section{Collection of experimental materials}

Caged layer excreta (CLE) was collected from Poultry Farm, Bangladesh Agricultural University (BAU), and Maize stover was collected from farmer's field, Mymensingh. For collection of layer droppings, polyethylene sheet was placed under the cage of birds. During collection enough care was taken so that the droppings would be free from feather, sand or other materials. Molasses and air tight plastic container (30L size) were purchased from local market.

\section{Preparation of wastelage}

Maize stover was collected just after collection of corn cobs. After collecting, stovers were chopped about 3-4 cm long. Then wastelage was prepared by mixing chopped stover with fresh poultry litter and molasses according to treatment formula. For proper mixing, first caged layer excreta and molasses were mixed then finally mixed with chopped stover.

Treatments:

$\mathrm{T}_{0}=0 \%$ caged layer excreta $+5 \%$ molasses + $95 \%$ maize stover

$\mathrm{T}_{1}=20 \%$ caged layer excreta $+5 \%$ molasses + $75 \%$ maize stover

$\mathrm{T}_{2}=40 \%$ caged layer excreta $+5 \%$ molasses + $55 \%$ maize stover

$\mathrm{T}_{3}=60 \%$ caged layer excreta $+5 \%$ molasses + $35 \%$ maize stover

Then these mixture groups were placed into airtight plastic containers which were previously marked according to the treatment. Finally plastic containers were kept in a room for 90 days for successful ensiling.

\section{Physical and organoleptic test of wastelage}

Texture (hardness), color and smell of samples were recorded. The results of these parameters were summarized according to the opinions of farms attendants, laboratory students of Department of Animal science, Bangladesh Agricultural University.

\section{Chemical analysis}

The samples of different treatments for wastelage were subjected to chemical analysis for organic matter $(\mathrm{OM})$, crude protein $(\mathrm{CP})$, crude fibre (CF), ether extract (EE) and total ash (TA) following the procedure of AOAC (2004) at Animal Science laboratory, Bangladesh Agricultural University, Mymensingh. Dry matter was determined by oven drying method. In vitro organic matter digestibility (IVOMD) and metabolizable energy (ME) content of wastelage were done following the method described by Menke et al. (1979).

\section{Statistical analysis}

The experiment was laid out in a $4 \times 4$ Factorial Design with 3 replicate in each treatment. Data were statistically analyzed using SAS Statistical Discovery Software, NC, USA and differences among the treatment means were determined by Duncan's Multiple Range Test (DMRT).

\section{Results}

\section{Physical properties and $\mathrm{pH}$ of wastelage}

The physical properties of wastelage of different treatments $\left(T_{0}, T_{1}, T_{2}\right.$ and $\left.T_{3}\right)$ at different ensiling period $(0,30,60$ and 90 days) are shown in 
Table 1. After 90 days of ensiling period, the color of different treatments $\left(T_{0}, T_{1}, T_{2}\right.$ and $T_{3}$ ) were light brown, brown, light chocolate and chocolate, respectively. The color of wastelage became deeper with the increasing level of CLE. Among all the treatments, $T_{1}$ and $T_{2}$ had good smell at 90 days of ensiling but $T_{3}$ had pungent smell which was not acceptable by cattle. Controlled treated wastelage remained hard after 90 days of ensiling but $T_{1}, T_{2}$ and $T_{3}$ became soft after 90 days of ensiling. Fungus propagation was not observed in poultry dropping treated wastelage but some seen in controlled treatment.

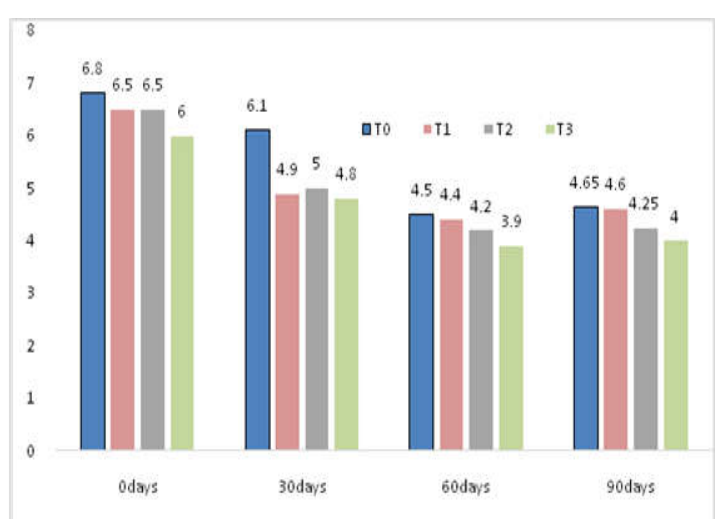

Figure 1: Effect of different treatments on $\mathrm{pH}$ of wastelage
The $\mathrm{pH}$ is shown in Figure 1 . Significant differences $(P<0.05)$ were observed among the treatments. The highest $\mathrm{pH}$ value was observed by treatment $T_{0}$ followed by $T_{1}, T_{2}$ and $T_{3}$. It was observed that $\mathrm{pH}$ value decreased with the increase level of CLE. The $\mathrm{pH}$ value was decreased significantly $(P<0.05)$ from 0 to 60 days with a slight increase in 90 days of ensiling which was statistically $(P>0.05)$ identical to 60 days.

\section{Chemical composition of wastelage \\ Dry Matter}

The dry matter content of wastelage of different treatments and different ensiling time is shown in Table 2. It was observed that Dry Matter (DM) content $(\mathrm{g} / 100 \mathrm{~g})$ of wastelage differ significantly $(P<0.01)$. The highest $D M$ was obtained by $T_{0}$ followed by $T_{1}, T_{2}$ and $T_{3}$. The reason of decreasing the DM content in the study may be due to fermentation with the higher level of CLE. Irrespective of treatment the DM at 0, 30, 60 and 90 days ensiling time were found $48.04 \%$, $41.38 \%, 39.20 \%$ and $36.67 \%$, respectively. It was observed that DM content was decreased with the ensiling time from $48.04 \%$ to $36.67 \%$ with the increase of duration from 0to 90 days $(P<0.01)$.

Table 1: Effect of different treatments on physical quality of wastelage

\begin{tabular}{|c|c|c|c|c|c|}
\hline \multirow[t]{2}{*}{ Characteristics } & \multirow[t]{2}{*}{ Observation } & \multicolumn{4}{|c|}{ Treatment } \\
\hline & & $\mathbf{T}_{\mathbf{0}}$ & $\mathbf{T}_{1}$ & $\mathbf{T}_{\mathbf{2}}$ & $\mathbf{T}_{3}$ \\
\hline \multirow{3}{*}{ Color } & 30 Days & Straw & Light brown & Brown & Light chocolate \\
\hline & 60 Days & Light brown & Brown & Light chocolate & Light chocolate \\
\hline & 90 Days & Light brown & Brown & Light chocolate & Chocolate \\
\hline \multirow{3}{*}{ Smell } & 30 Days & Straw & Bad odor & Bad odor & Bad odor \\
\hline & 60 Days & Straw & Bad odor & Bad odor & Bad odor \\
\hline & 90 Days & Straw & Acceptable smell & Good & Pungent \\
\hline \multirow{3}{*}{ Softness } & 30 Days & Hard & Hard & Hard & Hard \\
\hline & 60 Days & Hard & Hard & Moderate soft & Soft \\
\hline & 90 Days & Hard & Soft & Soft & Soft \\
\hline \multirow{3}{*}{ Fungus } & 30 Days & Absent & Absent & Absent & Absent \\
\hline & 60 Days & Present & Absent & Absent & Absent \\
\hline & 90 Days & Present & Absent & Absent & Absent \\
\hline
\end{tabular}


Jamee et al. (2019) Bang. J. Anim. Sci. 48 (2):75-84

Table 2: Effect of different treatments and different ensiling time on the dry matter of wastelage

\begin{tabular}{|c|c|c|c|c|c|c|c|}
\hline \multirow[b]{2}{*}{ Parameters } & \multirow[b]{2}{*}{ Days } & \multicolumn{4}{|c|}{ Treatments } & \multirow[b]{2}{*}{ Mean } & \multirow[b]{2}{*}{ SEM } \\
\hline & & $\mathbf{T}_{\mathbf{0}}$ & $\mathbf{T}_{1}$ & $\mathbf{T}_{2}$ & $\mathbf{T}_{3}$ & & \\
\hline \multirow{6}{*}{ Dry Matter } & 0 & 60.9 & 53.7 & 41.48 & 34.1 & $48.04^{a}$ & 0.028 \\
\hline & 30 & 52.9 & 39.84 & 41.06 & 31.72 & $41.38^{\mathrm{b}}$ & 0.033 \\
\hline & 60 & 49.4 & 41.2 & 37.82 & 28.34 & $39.20^{c}$ & 0.035 \\
\hline & 90 & 46.28 & 40.84 & 34.58 & 24.98 & $36.67^{d}$ & 0.037 \\
\hline & Mean & $52.36^{\mathrm{a}}$ & $43.90^{\mathrm{b}}$ & $38.74^{c}$ & $30.29^{d}$ & & \\
\hline & SEM & 0.026 & 0.031 & 0.035 & 0.045 & & \\
\hline
\end{tabular}

Means with different superscripts within row and column are significantly different $(P<0.01)$; SME: standard error of mean

The organic matter (OM) content of the treatments $\left(\mathrm{T}_{0}, \mathrm{~T}_{1}, \mathrm{~T}_{2}\right.$ and $\left.\mathrm{T}_{3}\right)$ were $83.90 \%$, $86.01 \%, 80.22 \%$ and $74.27 \%$, respectively which is shown in Table 3. In the present experiment the OM content was highest $(86.01 \%)$ in $\mathrm{T}_{1}$ and decreased $(P<0.01)$ with the increasing level of caged layer excreta and lowest $(74.27 \%)$ in $T_{3}$. The OM content of wastelage in different ensiling period $(0,30,60$, and 90 days) were $85.44 \%$, $78.36 \%, 78.09 \%$ and $82.51 \%$, respectively. The present study indicates that the OM content was decreased $(P<0.01)$ from $85.44 \%$ to $78.36 \%$ at 30 days. There was no significant difference ( $P>0.01$ ) among 30, 60 and 90 days, although there was a slight increase in 90 days.

\section{Crude Protein}

The crude protein (CP) content of different treatments $\left(T_{0}, T_{1}, T_{2}\right.$ and $\left.T_{3}\right)$ of wastelage were $9.979 \%, 13.41 \%, \quad 17.17 \%$ and $22.65 \%$, respectively has been shown in Table 4 . The highest $(22.65 \%) \mathrm{CP}$ content was found in $\mathrm{T}_{3}$ and lowest $(9.79 \%)$ CP content was found in $T_{0}$. The $\mathrm{CP}$ content differ with the addition of caged layer excreta (CLE) $(P<0.01)$. The CP content of wastelage in different ensiling period $(0,30,60$, and 90 days) were $13.49 \%, 16.03 \%, 16.37 \%$ and $17.11 \%$, respectively. It was observed that $\mathrm{CP}$ content was increased with the ensiling time from $13.49 \%$ to $17.11 \%$ with the time of 0 days to 90 days, respectively $(P<0.01)$.

\section{Crude Fibre}

The crude fibre (CF) content of wastelage of different treatments and different ensiling time are shown in Table 5 . The CF content of different treatments $\left(T_{0}, T_{1}, T_{2}\right.$ and $\left.T_{3}\right)$ of wastelage was $25.13 \%$, $22.64 \%, \quad 19.98 \%$ and $14.79 \%$, respectively. In the present experiment the value of CF was significantly higher (25.13\%) in controlled $T_{0}$ than treated $\left(T_{1}, T_{2}\right.$ and $\left.T_{3}\right)$ maize stovers. The CF content was decreased significantly $(P<0.01)$ from $25.13 \%$ to $14.79 \%$ with the addition of CLE ( 0 to $60 \%$ ). The CF content of wastelage in different ensiling period ( $0,30,60$, and 90 days) were $21.52 \%, 20.12 \%$, $20.34 \%$ and $20.55 \%$ respectively. It was observed that CF was decreased with ensiling period $(P<0.01)$ but again increased in 90 days $(20.55 \%)$ which was not statistically significant $(\mathrm{P}>0.01)$.

\section{Ether Extract}

The ether extract (EE) content of wastelage of different treatments and different ensiling period are shown in Table 6. Irrespective of ensiling period the EE content of different treatments $\left(T_{0}\right.$, $\mathrm{T}_{1}, \mathrm{~T}_{2}$ and $\mathrm{T}_{3}$ ) of wastelage were $3.38 \%, 3.37 \%$, $3.33 \%$ and $3.40 \%$, respectively. There were no significant differences ( $P>0.01)$ among treatments. EE content was also similar with increase the ensiling period up to 90 days.

\section{Ash}

The ash content of wastelage of different treatments and different ensiling period are shown in Table 7. The Ash content of different treatments $\left(T_{0}, T_{1}, T_{2}\right.$ and $\left.T_{3}\right)$ of wastelage was $13.84 \%$, $13.99 \%, \quad 19.78 \%$ and $25.68 \%$, respectively. The Ash content was not varied significantly $(P>0.01)$ between $T_{0}$ and $T_{1}$. The ash content was increased significantly $(P<0.01)$ with the increase of poultry litter percentage. The highest $(25.78 \%)$ ash content was found in $T_{3}$ and lowest (13.84\%) ash content found in $\mathrm{T}_{0}$. But the Ash content was increased significantly $(P<0.01)$ from $T_{1}(13.99 \%)$ to $T_{3}(25.68 \%)$. Irrespective of treatments, the Ash content of wastelage in different ensiling period $(0,30,60$, and 90 days) were $14.56 \%, 21.58 \%, 19.66 \%$ 


\section{Wastelage from Maize stover and poultry droppings}

and $17.49 \%$, respectively. It was observed that the ash content of wastelage with CLE and maize stover decreased with the increase of ensiling period from 30 to 90 days, although the value of 0 day was lower than that of 30 days $(P<0.01)$.

Table 3: Effect of different treatments and different ensiling time on the organic matter of wastelage

\begin{tabular}{|c|c|c|c|c|c|c|c|}
\hline \multirow{2}{*}{ Parameters } & \multirow{2}{*}{ Days } & \multicolumn{4}{|c|}{ Treatments } & \multirow[t]{2}{*}{ Mean } & \multirow[t]{2}{*}{ SEM } \\
\hline & & $\mathbf{T}_{0}$ & $\mathbf{T}_{1}$ & $\mathbf{T}_{2}$ & $\mathbf{T}_{3}$ & & \\
\hline \multirow{6}{*}{ Organic Matter } & 0 & 87.44 & 86.31 & 86.64 & 80.41 & $85.44^{\mathrm{a}}$ & 0.012 \\
\hline & 30 & 85.25 & 84.89 & 76.18 & 67.34 & $78.36^{\mathrm{b}}$ & 0.013 \\
\hline & 60 & 85.67 & 86.17 & 78.01 & 71.56 & $78.09^{b}$ & 0.013 \\
\hline & 90 & 86.26 & 86.73 & 80.10 & 76.95 & $82.51^{\mathrm{ab}}$ & 0.012 \\
\hline & Mean & $83.90^{\mathrm{ab}}$ & $86.01^{a}$ & $80.22^{\mathrm{b}}$ & $74.27^{c}$ & & \\
\hline & SEM & 0.012 & 0.011 & 0.012 & 0.013 & & \\
\hline
\end{tabular}

Means with different superscripts within row and column are significantly different $(P<0.01)$; SME: standard error of mean.

Table 4: Effect of different treatments and different ensiling time on the crude protein of wastelage

\begin{tabular}{|c|c|c|c|c|c|c|c|}
\hline \multirow{2}{*}{ Parameters } & \multirow{2}{*}{ Days } & \multicolumn{4}{|c|}{ Treatments } & \multirow[t]{2}{*}{ Mean } & \multirow[t]{2}{*}{ SEM } \\
\hline & & $\mathbf{T}_{0}$ & $\mathbf{T}_{1}$ & $\mathbf{T}_{2}$ & $\mathbf{T}_{3}$ & & \\
\hline \multirow{6}{*}{ Crude Protein } & 0 & 9.31 & 10.12 & 15.38 & 19.09 & $13.49^{d}$ & 0.055 \\
\hline & 30 & 11.43 & 14.43 & 15.17 & 22.79 & $16.03^{c}$ & 0.047 \\
\hline & 60 & 9.83 & 14.29 & 17.61 & 23.75 & $16.37^{\mathrm{b}}$ & 0.046 \\
\hline & 90 & 8.12 & 14.78 & 20.53 & 24.94 & $17.11^{\mathrm{a}}$ & 0.044 \\
\hline & Mean & $9.797^{d}$ & $13.41^{\mathrm{c}}$ & $17.17^{\mathrm{b}}$ & $22.65^{a}$ & & \\
\hline & SEM & 0.077 & 0.056 & 0.044 & 0.033 & & \\
\hline
\end{tabular}

Means with different superscripts within row and column are significantly different $(P<0.01)$; SME: standard error of mean.

Table 5: Effect of different treatments and different ensiling time on the crude fiber of wastelage

\begin{tabular}{|c|c|c|c|c|c|c|c|}
\hline \multirow{2}{*}{ Parameters } & \multirow{2}{*}{ Days } & \multicolumn{4}{|c|}{ Treatments } & \multirow[t]{2}{*}{ Mean } & \multirow[t]{2}{*}{ SEM } \\
\hline & & $\mathbf{T}_{\mathbf{0}}$ & $\mathbf{T}_{1}$ & $\mathbf{T}_{2}$ & $\mathbf{T}_{3}$ & & \\
\hline \multirow{6}{*}{ Crude Fibre } & 0 & 27.95 & 24.15 & 17.35 & 16.65 & $21.52^{\mathrm{a}}$ & 0.028 \\
\hline & 30 & 25.25 & 21.25 & 20.15 & 13.85 & $20.12^{c}$ & 0.030 \\
\hline & 60 & 24.2 & 22.15 & 20.85 & 14.15 & $20.34^{b c}$ & 0.029 \\
\hline & 90 & 23.1 & 23.05 & 21.55 & 14.50 & $20.55^{b}$ & 0.029 \\
\hline & Mean & $25.13^{\mathrm{a}}$ & $22.64^{b}$ & $19.98^{c}$ & $14.79^{d}$ & & \\
\hline & SEM & 0.024 & 0.026 & 0.030 & 0.040 & & \\
\hline
\end{tabular}

Means with different superscripts within row and column are significantly different $(P<0.01)$; SME: standard error of mean. 
Jamee et al. (2019) Bang. J. Anim. Sci. 48 (2):75-84

Table 6: Effect of different treatments and different ensiling time on the ether extract of wastelage

\begin{tabular}{ccccccccc}
\hline \multirow{2}{*}{ Parameters } & Days & \multicolumn{9}{c}{ Treatments } & \multirow{2}{*}{ Mean } & \multirow{2}{*}{ SEM } \\
\cline { 3 - 6 } & & $\mathbf{T}_{\mathbf{0}}$ & $\mathbf{T}_{\mathbf{1}}$ & $\mathbf{T}_{\mathbf{2}}$ & $\mathbf{T}_{\mathbf{3}}$ & & \\
\hline \multirow{3}{*}{ Ether Extract } & 0 & 3.39 & 3.38 & 3.39 & 3.38 & $3.38^{\mathrm{a}}$ & 0.015 \\
& 30 & 3.38 & 3.37 & 3.25 & 3.40 & $3.35^{\mathrm{b}}$ & 0.016 \\
& 60 & 3.38 & 3.36 & 3.36 & 3.41 & $3.37^{\mathrm{a}}$ & 0.016 \\
& 90 & 3.39 & 3.40 & 3.35 & 3.42 & $3.37^{\mathrm{a}}$ & 0.016 \\
& Mean & $3.38^{\mathrm{ab}}$ & $3.37^{\mathrm{b}}$ & $3.33^{\mathrm{c}}$ & $3.40^{\mathrm{a}}$ & & & \\
& SEM & 0.015 & 0.016 & 0.017 & 0.014 & & \\
\hline
\end{tabular}

Means with different superscripts within row and column are significantly different $(P<0.01)$; SME: standard error of mean.

\section{Nutritive value of wastelage}

\section{In vitro organic matter digestibility (IVOMD)}

The in vitro organic matter digestibility (OMD) of wastelage at different treatments $\left(T_{0}, T_{1}, T_{2}\right.$ and $\left.\mathrm{T}_{3}\right)$ and at different ensiling period $(0,30,60$ and 90 days) are shown in Table 8 . Irrespective of ensiling period, the OMD of different treatments were $59.28 \%, 58.51 \%, 63.91 \%$ and $63.86 \%$, respectively. The OMD increased significantly $(P<0.01)$ with the increase of CLE. Irrespective of treatments, the OMD in different ensiling period $(0,30,60$ and 90 days) were $58.74 \%, 61.02 \%$, $62.45 \%$ and $63.36 \%$, respectively. The OMD was increased statistically $(P<0.01)$ with the increase of ensiling period.

\section{Metabolizable Energy (ME)}

The Metabolizable Energy (ME) content (MJ/Kg DM) of wastelage at different treatments $\left(T_{0}, T_{1}\right.$, $T_{2}$ and $\left.T_{3}\right)$ and at different ensiling period $(0,30$, 60 and 90 days) are shown in Table 9. Irrespective of ensiling period, the ME content of different treatments were $7.83,8.02,8.70$ and $8.60 \mathrm{MJ} / \mathrm{Kg} \mathrm{DM}$, respectively. The ME content was statistically $(P<0.01)$ increased with the increase of CLE. The highest (8.70) ME content was found in $T_{2}$ which was statistically $(P>0.01)$ identical to $T_{3}$. The lowest (7.83) ME content was found in controlled treatment $\left(T_{0}\right)$. Irrespective of treatments, the $\mathrm{ME}$ content $(\mathrm{MJ} / \mathrm{Kg} \mathrm{DM})$ in different ensiling period $(0,30,60$ and 90 days) were $8.01,8.09,8.43$ and $8.62 \mathrm{MJ} / \mathrm{Kg} \mathrm{DM}$, respectively. The highest (8.62) ME content was found in $T_{3}$ followed by $T_{2}, T_{1}$ and $T_{0}$.

Table 7: Effect of different treatments and different ensiling time on the ash content of wastelage

\begin{tabular}{cccccccc}
\hline \multirow{2}{*}{ Parameters } & Days & \multicolumn{9}{c}{ Treatments } & Mean & SEM \\
\cline { 3 - 6 } & & $\mathbf{T}_{\mathbf{0}}$ & $\mathbf{T}_{\mathbf{1}}$ & $\mathbf{T}_{\mathbf{2}}$ & $\mathbf{T}_{\mathbf{3}}$ & & \\
\hline \multirow{3}{*}{ Ash } & 0 & 12.56 & 13.69 & 13.36 & 19.59 & $14.56^{\mathrm{d}}$ & 0.060 \\
& 30 & 14.75 & 15.11 & 23.82 & 32.66 & $21.58^{\mathrm{a}}$ & 0.040 \\
& 60 & 14.33 & 13.83 & 21.99 & 28.44 & $19.66^{\mathrm{b}}$ & 0.044 \\
& 90 & 13.74 & 13.27 & 19.90 & 2305 & $17.49^{\mathrm{c}}$ & 0.050 \\
& Mean & $13.84^{\mathrm{c}}$ & $13.99^{\mathrm{c}}$ & $19.78^{\mathrm{b}}$ & $25.68^{\mathrm{a}}$ & & \\
& SEM & 0.063 & 0.062 & 0.044 & 0.034 & & \\
\hline
\end{tabular}

Means with different superscripts within row and column are significantly different $(P<0.01)$; SME: standard error of mean. 
Wastelage from Maize stover and poultry droppings

Table 8: In vitro organic matter digestibility (IVOMD) of wastelage at different treatments and different ensiling period

\begin{tabular}{cccccccc}
\hline \multirow{2}{*}{ Parameters } & Days & \multicolumn{9}{c}{ Treatment } & Mean & SEM \\
\cline { 3 - 6 } & & $\mathbf{T}_{\mathbf{0}}$ & $\mathbf{T}_{\mathbf{1}}$ & $\mathbf{T}_{\mathbf{2}}$ & $\mathbf{T}_{\mathbf{3}}$ & & \\
\hline & 0 days & 55.08 & 56.75 & 61.03 & 62.09 & $58.74^{\mathrm{d}}$ & 1.68 \\
Organic Matter & 30 days & 60.63 & 56.45 & 63.24 & 63.74 & $61.02^{\mathrm{c}}$ & 1.67 \\
Digestibility (OMD) & 60 days & 60.66 & 59.26 & 65.35 & 64.51 & $62.45^{\mathrm{b}}$ & 1.47 \\
& 90 days & 60.74 & 61.56 & 66.03 & 65.09 & $63.36^{\mathrm{a}}$ & 1.30 \\
& Mean & $59.28^{\mathrm{b}}$ & $58.51^{\mathrm{b}}$ & $63.91^{\mathrm{a}}$ & $63.86^{\mathrm{a}}$ & & \\
& SEM & 1.40 & 1.20 & 1.13 & 0.65 & & \\
\hline
\end{tabular}

Means with different superscripts within row and column are significantly different $(P<0.01)$; SME: standard error of mean.

Table 9: Metabolizable energy (ME) content of wastelage at different treatments and different ensiling period

\begin{tabular}{cccccccc}
\hline \multirow{2}{*}{ Parameters } & Days & \multicolumn{9}{c}{ Treatment } & Mean & SEM \\
\cline { 3 - 6 } & & $\mathbf{T}_{\mathbf{0}}$ & $\mathbf{T}_{\mathbf{1}}$ & $\mathbf{T}_{\mathbf{2}}$ & $\mathbf{T}_{\mathbf{3}}$ & & \\
\hline \multirow{3}{*}{$\begin{array}{c}\text { Metabolizable Energy } \\
\text { (ME) }\end{array}$} & 0 days & 7.57 & 7.80 & 8.20 & 8.46 & $8.01^{\mathrm{b}}$ & 0.20 \\
& 30 days & 7.70 & 7.74 & 8.40 & 8.52 & $8.09^{\mathrm{b}}$ & 0.22 \\
& 60 days & 7.95 & 8.10 & 9.03 & 8.63 & $8.43^{\mathrm{ab}}$ & 0.25 \\
& 90 days & 8.10 & 8.42 & 9.15 & 8.79 & $8.62^{\mathrm{a}}$ & 0.23 \\
& Mean & $7.83^{\mathrm{c}}$ & $8.02^{\mathrm{b}}$ & $8.70^{\mathrm{a}}$ & $8.60^{\mathrm{a}}$ & & \\
& SEM & 0.12 & 0.16 & 0.23 & 0.07 & & \\
\hline
\end{tabular}

Means with different superscripts within row and column are significantly different $(P<0.01)$; SME: standard error of mean.

\section{Discussion}

At different level of layer excreta and ensiling period, prepared wastelage had different physical qualities. Good color and aroma was obtained when poultry manure was ensiled with maize forage (Harmon et al., 1975), citrus pulp or weeds (Hadjipanayiotou, 1982). Bostami et al. (2009) reported that maize stover ensiled with urea had no fungal growth but observed in untreated maize stover silage. Schroeder (2013) reported that properly ensiled silage had good color and desirable smell. The lower $\mathrm{P}^{\mathrm{H}}$ of wastelage indicates good fermentation quality which was due to presence of higher water soluble carbohydrates in fodder that enhanced lactic acid production (Yunus et al., 2000). Roothaert et al. (1992) indicated that ensiled materials should reach a $\mathrm{PH}$ of less than 5 in order to destroy Salmonella and other pathogens. Lower $\mathrm{pH}$ level helps to facilitate preservation of the silage and faster fermentation of the silage helps to retain more nutrients in the silage (Schroeder, 2013). In the present studies, $\mathrm{pH}$ values lower than 5 were attained in all wastelage indicated that they are highly fermented and lactic acid production is higher which will help to conserve more nutrients in the wastelage.

The reason of decreasing the DM content in the study maybe due to fermentation with the higher level of CLE. The DM loss also found by Otieno et al. (1986); Hiep and Man (2003); Man and Wiktorsson (2003). There some experiments where same findings were also obtained. It was observed that DM decreased in ensiled maize stover from 22.58 to $20.83 \%$ (Otieno et al., 1986), from 29.1 to $26.5 \%$ (Hiep and Man 2003). Snijder and Wonters (2004) reported DM loss in ensiled maize stover was $81 \%$. DM content of maize stover was reduced from 28.0 to $26.4 \%$, with increasing the ensiling time from 2 to 4 months (Man and Wiktorsson, 2003). Losses of DM may come from run off, oxidation and loss of volatile organic compounds (Kung, 2010). 
This study showed the decrease of OM in wastelage with ensiling period and higher level of layer excreta. Similarly, OM was decreased with the urea treatment of maize stover (Smith et al., 1989). With caged layer waste (nitrogen source) ensiling of maize stover, wheat straw and maize cobs the OM content was decreased (Kayongo et al., 1986).OM content slightly increased with increasing time when maize stover ensiled with caged layer waste (nitrogen source) (Kayongo et al., 1986). Due to ensiling time in the presence or absence of additives, organic matter may be increased or decreased, which may be depends on different factors such as biochemical or microbial reactions during ensiling period.

With different treatment and ensiling time the CP increase with the increase of poultry droppings and with time. Daniels et al. (1983) reported that maize stover ensiled broiler litter for 6 weeks and found that CP was increased with increased proportion of poultry litter. The crude protein of sorghum forages ensiled with broiler litter increased with increased proportion of poultry litter (Al-Rokayan et al. 1988; Flachowsky and Henning 1990). Ngele et al. (2006) ensiled rice straw with poultry litter at different ratios and recorded highest crude protein in ratio 50:50. Ensiling time increase the $\mathrm{CP}$ content when maize stover ensiled with nitrogen source (caged layer waste) (Kayongo et al., 1986). Similar results have been reported by Daniels et al. (1983) and Hadjipanaytou (1984). The result supported by Mohanta (2005), who stated that, in different days ( 7,15 and 21 days) of ensiling CP content were different and were highest in 21 days.

Decrease in CF had been found from the present study. Baba et al. (2010), who reported that when Kyasuwa hay (Pennisetum pedicellatum) ensiled with poultry litter at treatment $80: 20$ and 50:50 the CF was decreased from $20.46 \%$ to $15.95 \%$. Magar and Fontenot (1988) and Rasoolo et al. (1996) also observed a similar trend in rice straw ensiled with poultry litter. CF decreased with the level of caged layer waste (nitrogenous source) in the maize stover (Kayongo et al., 1986). The reason of CF decrease may be due to the lower CF content of CLE and also decomposition of silage materials. CF was reduced with increasing the ensiling time, when ensiled with caged layer waste (nitrogenous source) (Kayongo et al., 1986). CF reduced with ensiling time (Man and Wiktorsson 2003). Baba et al. (2010) reported that when Kyasuwa hay (Pennisetum pedicellatum) ensiled with poultry litter, EE declined with increased proportion of poultry litter. Variation of the present observation may due to the variation of poultry litter and ensiling materials.

Variation in ash content of wastelage was shown with different treatments in this study. This result is supported by Al-Rokayan et al. (1988) and Flachowsky and Hennig (1990), who observed a linear increase in ash with increased proportion of broiler litter. Kim et al. (2014), who indicated that ash content of silage increase up to 28 days of ensiling.

Organic matter digestibility of our study significantly increased with the time of ensiling period. On the other hand, first two treatments had significance difference with last two treatments. This result is partially supported by Reddy and Reddy (1980), who reported that in vitro organic matter digestibility of rice straw increase when ensiled with rumen digesta and animal excreta. Saylor and Long (1972) reported that in vitro organic matter digestibility of ensiled crop residue and poultry manure positively increased with the level of poultry manure. Predicted OMD was increased in maize stover ensiled with caged layer waste (Kayongo et al., 1986). Boever et al. (2013) reported that in vitro organic matter digestibility of ensiled grass was $82.3 \%$ and $83.9 \%$ after 60 and 150 days of ensiling, respectively.

The result of ME of wastelage of our study is supported by Ali et al. (1994), who reported that ME were increased in treated compared with untreated stover after ensiling. Bostami et al. (2009) also reported that ME content was increased in treated ensiled maize stover than untreated ensiled maize stover. Cone et al. (2007) reported ensiling period has no significant $(P>0.01)$ effect on ME content of silage.

\section{Conclusion}

The results suggested that ensiling of maize stover with $40 \%$ poultry droppings had significant improvement of nutritional values of wastelage and may be a feasible means of converting layer excreta into a palatable and nutritious feed for cattle. Besides feed preparation, this approach may also solve the disposal problem of poultry droppings in large poultry industries by utilizing it as an animal feed which in terms contribute in environment-friendly animal production systems.

\section{Conflict of interest}

The author has no conflict of interest to declare. 


\section{References}

Ali I, JP Fontenot and VG Allen (1994). Fermentation characteristics, chemical changes and in vitro dry matter digestibility of corn stover treated with different sources of nitrogen (small silo study). Pakistan Veterinary Journal 14(4):185193.

Al-Rokayan SA, Z Naseer and SM Chaudhry (1988). Nutritional quality and digestibility of sorghumbroiler litter silages. Animal Feed Science and Technology 75:65-73.

AOAC (2004). Association of the Official Agricultural Chemists, Official methods of analysis. Washington, DC, pp. 1-34.

Baba M, T Uba and AR Halim (2010). Nutritive value of Kyasuwa hay (Pennisetum pedicellatum) ensiled with poultry litter at varying proportions. Research Journal of Animal Science 4:17-120.

Bhattacharya AN and JC Taylor (1975). Recycling animal waste as a feedstuff: a review. Journal Animal of Science 41:1438-1457.

Boever JL, E Dupon, E Wambacq and J Latre (2013). The effect of a mixture of lactobacillus strains on silage quality and nutritive value of grass harvested at four growth stages and ensiled for two periods. Agricultural and Food Science 22:115-126.

Bostami AB, RI Khan, MM Rahman, AMondal, NR Sarker and MR Hasan (2009). Study on the effect of ensiling with or without urea on physical quality, chemical composition and in vitro digestibility of maize stover. Journal of Agroforestry and Environment 3(1):167-171.

Cone JW, AH Van Gelder, HA Van Schooten and JA Groten (2008). Effects of chop length and ensiling period of forage maize on in vitro rumen fermentation characteristics. NJASWageningen Journal of Life Sciences 55(2):155166.

Cook SL, J Michael and N Lovanh (2011). Evaluation of nitrogen retention and microbial populations in poultry litter treated with chemical, biological or adsorbent amendments. Journal of Environmental Management 92:1760-1766.

Daniels LB, MJ Smit, OT Stallcup and JM Rakes (1983). Nutritive value of ensiled broiler litter for cattle. Animal Feed Science and Technology $8(1): 19-24$

Department of Livestock Services (2018). Livestock economy at a glance. Ministry of Livestock and Fisheries, Government of the people Republic of Bangladesh.

El-Sabban FF, JW Bratzler, TA Long, DEH Frear and RF Gentry (1970). Value of processed poultry waste as a feed for ruminants. Journal of Animal Science 31:107-11l.

Flachowsky G and A Hennig (1990). Composition and digestibility of untreated and chemically treated animal excreta for ruminants-A review. Biological waste, 31: 17-36.
Fontenot JP (1981) Recycling of Animal wastes by Feeding. In: New protein Foods, Volume 4,pp.277-304.

Fontenot JP and KE Webb, BW Harmon, RE Tucker and WEC Moore (1971). Studies of processing, nutritional value and portability of broiler litter for ruminants Proc. Int. Symp. on Livestock wastes, ASAE, St. Joseph, MI. p. 301.

Hadjipanayioto M (1984). The use of poultry litter as ruminant feed in Cyprus. World Animal Review 49:32-38.

Hadjipanayiotou M (1982). Laboratory evaluation of ensiled poultry litter. Animal Production 35:157161.

Harmon BW, JP Fontenot and KE Webb (1975). Ensiled broiler litter and corn forage. II. Digestibility, nitrogen utilization and palatability by sheep. Journal of Animal Science 40:156160.

Hiep NV and NV Man (2003). Dairy Cattle feed from stover derived from mature and immature maize crops in small holder crop-livestock production system in Vietnam. University of Agriculture and Forestry, Thu Duc, Ho Chi Minh city, Vietnam. mammy@hcm.vnn.vn.

Hossain MK, V Strezov, KY Chan and PF Nelson (2010). Agronomic properties of wastewater sludge biochar and bioavailability of metals in production of cherry tomato (Lycopersicone sculentum). Chemosphere 78:1167-1171.

Islam MS (2013). Impact of different factors on biogas production in poultry dropping based biogas plants of Bangladesh. Journal of Energy and Natural Resources 2(4):25-32.

Khatun H, RI Khan and M Moniruzzaman (2013). Preparation of Wastelage with Poultry Droppings and Oat Forage (Avena sativa) as a Feed for Cattle. Journal of Environmental Science and Natural Resources, 6(1): 233- 237

Kayongo SB, MM Wanyoike, PN Nyagah, PN Maitho and PN Mbugua (1986). Caged layer waste as nitrogen source in crop-residue utilization. Department of Animal Production, Faculty of Veterinary Medicine, University of Nairobi, Nairobi, Kenya.

Kim YI, YK Oh, KK Park, WS Kwak (2014). Ensiling Characteristics and the In situ Nutrient Degradability of a By-product Feed-based Silage. Asian Australian Journal of Animal Science 27(2):201-208.

Kung JL (2010). Understanding the biology of silage preservation to maximize quality and protect the environment. In Proceedings, 2010 California Alfalfa and Forage Symposium and Corn/Cereal Silage Conference. pp. 12.

Lu J and N Kevern N (1975). The feasibility of using waste materials as supplemental fish feed. Progressive Fisheries Culture 37:241-244.

Magar SM and JP Fontenot (1988). Nutritional value of ensiled deep pit caged layer waste-corn forage mixtures. Virginia Technical Livestock Research Report No 7, Blacksburg, pp: I33-136. 


\section{Jamee et al. (2019) Bang. J. Anim. Sci. 48 (2):75-84}

ManNandH W (2003).The effect of molasses on quality, feed intake and digestibility by heifers of silage made from cassava tops. Department of Animal Nutrition, UAF, Thu Duc, Ho Chi Minh City, Vietnam.

Mavimbela DT (2000). The nutritional value of broiler litter as a feed source for sheep during periods of feed shortage. PhD Thesis, Department of Animal and Wildlife Sciences, Faculty of Agriculture, University of Pretoria.

Mc.Donald P, RA Edwards and JJD Greenhalgh (1995). Animal Nutrition. 5th Edition. pp: 7581.

Menke KH, L Raab, A Salewski, H Steingass, D Fritz and $W$ Schneider (1979). The estimation of the digestibility and metabolizable energy content of ruminant feeding stuffs from the gas production when they are incubated with rumen liquor in vitro. Journal of Agricultural Science 93:217222

Mohanta NG (2005). Improvement of the nutritive value of rice straw through treatment with urea, urease sources and plant leaves. M.S. Thesis, Department of Animal Nutrition. Bangladesh Agricultural University, Mymensingh.

Ngele MA, TA Adegbola and SE Bogoro (2006). Nutritive value of rice straw treated with poultry litter. In Proceedings of the 31st Annual Conference of Nigerian Society for Animal Production, March (pp. 12-15).

Islam O, S Akter, MA Islam, DK Jamee and RI Khan (2018). Preparation of wastelage with poultry droppings and rice straw (Oryza sativa L.) as a cattle feed. Asian Journal of Medical and Biological Research. 4(3):251-258

Otieno K, JFM Onim and MN Mathuva (1986). A gunny bag ensiling technique for small scale farmers in Western Kenya. Ministry of Livestock Department /SR-CRSP, Maseno, Kenya.

Panna MSJ, SMA Islam, AKMA Kabir and MRI Khan (2019) Preparation and nutritional evaluation of wastelage using poultry droppings and napier grass. Bangladesh Journal of Animal Science 48 (1):48-56

Rasool S, SH Hanjra and A Jamil (1996). Effect of ensiling sudax fodder with broiler litter and Candida yeast on the changes in different fiber fractions. Animal Feed Science and Technology 57(4):325-333.

Rathi S (2006). Alternative approaches for better municipal solid waste management in Mumbai, India. Waste Management 26(10):192-1200.

Reddy MR and KVS Reddy (1980). A short note on the proximate composition of rumen digesta from bovine and ovine species and its utilization as a component of livestock feed. Indian Veterinary Journal 57(5):429-431.

Ritz CW, BD Fairchild and MP Lack (2004). Implications of ammonia production and emissions from commercial poultry facilities: a review. Journal of Applied Poultry Research13:684-692.

Roothaert RL and RW Matthewman (1992). Poultry wastes as foods for ruminants and associated aspects of animal welfare - Review. American Journal of Animal Science 5(4):593-600.

Saylor WW and TA Long (1972). Laboratory evaluation of ensiled poultry waste. Journal of Animal Science 39:139-145.

Schroeder JW (2013). Silage fermentation and preservation. NDSU Extension service. AS1254.

Smith T, C Chakanyuka, S Sibanda and B Manyuch (1989). Maize stover as a feed for ruminants. Department of Research and Specialist services, Grasslands Research Station, Marondera, Zimbabwe. Proceedings of a workshop held in Malawi, ARNAB, ILCA, Addis Ababa, Ethiopia. pp. 218-231.

Snijders PJM and AP Wouters (2004). Silage quality and losses due to ensiling of Napier grass, Colombus grass and Maize stover under small holder conditions in Kenya. FAO Electronic Conference on Tropical Silage.

Strickler RH (1977). Deep stacking broiler litter as a means of storage for use in feeding beef cows In: alternate nitrogen sources for ruminants, pp.56-57. Conference, 9-11 November 1977, Atlanta, Georgia, USA.

Yunus M, N Ohba, M Shimojo, M Furuse and $Y$ Masuda (2000). Effects of adding urea and molasses on Napier grass silage quality. AsianAustralian Journal of Animal Science 13(11):1542-1547. 